\title{
Mortars and Concrete Incorporating Palm Oil Fuel Ash and Fly Ash
}

\author{
Yvonne William Tonduba ${ }^{1 *}$, Jahangir Mirza ${ }^{1,2}$ \\ ${ }^{1}$ Civil and Construction Engineering Department, Faculty of Engineering and Science, Curtin University, Malaysia \\ ${ }^{1,2}$ Dept. of Materials Science, Research Institute of Hydro-Quebec, Hydro-Québec Materials Science, Canada \\ *Corresponding author: yvonnewill@postgrad.curtin.edu.my
}

\begin{abstract}
Number of researchers reported that Palm Oil Fuel Ash (POFA) and Fly Ash (FA) can be used as supplementary cementing material (SCM) in concrete. Both materials have their own significant effects on the properties of concrete and have been accepted by using them for the improvement of workability and strength of concrete. However, studies showed that FA has better pozzolanic properties than POFA. Hence, properties of mortars blended with POFA (untreated and treated) as binary blend (CUP and CTP) and ternary blend that combined with FA (CUPF and CTPF) as cement replacement were investigated. Unground POFA has been used in this study. CUPF and CTPF resulted in significant improvement in the pozzolanic activity compared to CUP and CTP of mortar mix. Pozzolanic activity of ternary blend mortar achieved the specified pozzolanic activity index of $75 \%$ based on ASTM C618. Compressive strength of the C80P15F5 concrete with $15 \%$ of treated POFA + 5\% of FA by weight of binder showed a slightly higher result compared to the control mix. It is suggested that the combination of POFA and FA as pozzolanic material will improves the mechanical properties of mortars and concrete.
\end{abstract}

Keywords-Binary blend, Ternary blend, Palm Oil Fuel Ash, Fly ash, Pozzolanic strength index, Compressive strength

\section{INTRODUCTION}

The reaction between the active phases of the pozzolans with lime is called the pozzolanic activity [1]. The pozzolans will react with calcium hydroxide $\left(\mathrm{Ca}(\mathrm{OH})_{2}\right)$ that is formed during the hydration process of cement and water. The reaction will then produce the secondary calcium-silicates-hydrates (C-S-H) gel which refines pore size distribution and enhances mechanical properties and durability [2].

There are several factors affecting the pozzolanic activity of a blended concrete, such as the chemical composition, fineness of the particles, structure of particles, etc. ASTM C618 states that to be considered as pozzolans, a material must obtain: minimum $70 \%$ of the total three main oxides $\left(\mathrm{SiO}_{2}+\mathrm{Al}_{2} \mathrm{O}_{3}+\mathrm{Fe}_{2} \mathrm{O}_{3}\right)$, maximum $34 \%$ retained on sieve size $45 \mu \mathrm{m}$, minimum $75 \%$ strength activity index and maximum $10 \%$ loss on ignition (LOI).

The study on applicability of concrete with POFA was initially started by Tay (1990) [3]. He used POFA passing sieve size $150 \mu \mathrm{m}$ to replace cement. He discovered that the compressive strength of a mix containing $10 \%$ of POFA by weight of binder, as cement replacement was the same as the control concrete. The research on utilizing POFA in concrete has been growing since then and particles size became the issue for improvement of concrete properties [4] [5]. The finer the POFA size, the better the strength properties of concrete are when blended with POFA [6]. Mostly, the raw POFA collected from the palm oil mill is in coarse particles size. Therefore, POFA was ground up to 8 hours to get the sufficient fineness using a ball mill [7].
Few studies were conducted to differentiate the effects of POFA and FA towards the concrete properties respectively. FA was reported to be a better pozzolan than that of POFA [8] [9]. Isaia et al. [10] stated that the benefits of FA is due to their physical effect and the deflocculating of cement grains provided by $\mathrm{FA}$ is higher than POFA. Studies in combining ground POFA and FA at equal weight as ternary blend proven to improve the pozzolanic activity and compressive strength of a blended concrete, compared to concrete blended with POFA only [11] [12] [13].

This study investigated the incorporation of combined unground POFA and FA as cement replacement in concrete to enhance the properties of concrete. The advantages of the FA were adopted in the ternary blended concrete.

\section{EXPERIMENTAL PROGRAM}

\section{A. Materials}

Locally available Ordinary Portland cement (OPC) (Type 1) complying with the standard specification was used. POFA was collected from a palm oil mill at Bekenu Miri, Sarawak Malaysia. POFA was first dried in the oven at $105^{\circ} \mathrm{C}$ to remove all the moisture content. Then the sample was sieved passing sieve size $150 \mu \mathrm{m}$ and put in the furnace at $550^{\circ} \mathrm{C}$ in 24 hours for heat treatment process. $80 \%$ of the POFA that retained on sieve size $45 \mu \mathrm{m}$ (No. 325) was used. Class F FA with mean diameter of $16 \mu \mathrm{m}$ was obtained from coal-fired power station in Sejinggat, Kuching [14]. The size of coarse aggregates used was within the range of 4.75$9.55 \mathrm{~mm}$. The fine aggregate used was the combination of fine quarry dust and natural silica sand with fineness modulus of 3.28. Quarry dust was used to fulfill the fine aggregates gradation requirement as natural sand was very fine. The sieve analysis of fine aggregates is presented in Figure 1. A highly purified lignosulphonate 
superplasticizer was used to improve the flow characteristics of the fresh concrete.

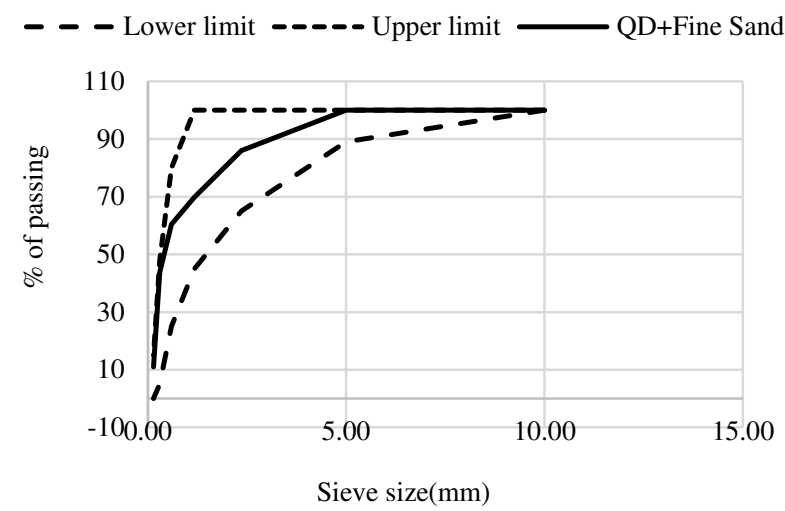

Figure 1. Sieve analysis of fine aggregates

\section{B. Mixture Proportions \\ 1. Mortar}

The mixture proportion of mortar is obtained from ASTM C618 for pozzolanic activity test and presented in Table 1. The binder content was kept constant at $500 \mathrm{~g} / \mathrm{m} 3$ with water to binder ratio 0.5 . Cement was replaced by $20 \%$ pozzolans by weight of binder for the blended mortar. Control mix represents the zero pozzolans mixture. CUP and CTP are blended mortar mixtures containing untreated and treated POFA respectively. Mixes blended with FA was represented as CF. CUPF and CTPF represent combined blend of untreated POFA with FA and treated POFA with FA respectively. POFA and FA were mixed with equal weight in ternary blend. All mortars were cast in 50x50x50mm molds for 6 specimens for each mix. After 24 hours of casting, the specimens were removed from the molds and immersed in the water for curing process for 7 and 28 days.

\section{Concrete}

Table 2 shows the mix proportions of the blended concrete. Absolute volume method was used to calculate the concrete mixture proportions. Cement content was kept constant at $450 \mathrm{~kg} / \mathrm{m} 3$ with water to binder ratio at 0.4. Only treated POFA was used for the concrete production. Binary blend of concrete produced with $80 \%$ of cement $+20 \%$ of POFA by weight of binder. Ternary blend produced with $80 \%$ cement $+15 \%$ POFA $+5 \%$ FA by weight of binder. 6 specimens were cast in 100x100x100mm mold for every mix. All the specimens were immersed in the water for curing process for 7 and 28 days.

Table 1. Mortar mix proportions

\begin{tabular}{lccccc}
\hline Mixes & $\begin{array}{c}\text { Cement } \\
(\mathbf{g})\end{array}$ & $\begin{array}{c}\text { POFA } \\
(\mathbf{g})\end{array}$ & $\begin{array}{c}\text { FA } \\
(\mathbf{g})\end{array}$ & $\begin{array}{c}\text { Fine Agg. } \\
(\mathbf{g})\end{array}$ & $\begin{array}{c}\text { Water } \\
(\mathbf{m l})\end{array}$ \\
\hline Control & 500 & - & - & 1350 & 250 \\
CUP & 400 & 100 & - & 1350 & 250 \\
CTP & 400 & 100 & - & 1350 & 250 \\
CUPF & 400 & 50 & 50 & 1350 & 250 \\
CTPF & 400 & 50 & 50 & 1350 & 250 \\
CF & 400 & - & 100 & 1350 & 250 \\
* CUP: cement + untreated POFA & & & \\
CTP: cement + treated POFA & & & \\
CUPF: cement + untreated POFA $+F A$ & & \\
CTPF: cement + treated POFA + FA &
\end{tabular}

\section{Testing of samples}

1. Characterizations

Chemical composition of cement, POFA and FA were determined using X-ray fluorescence (XRF) spectrometry analysis. Scanning Electron Microscopy (SEM) analysis was used to generate high-resolution images of cement, POFA and FA, to investigate the structure and shape of particles.

\section{Pozzolanic strength index}

Mortar specimens were used to investigate the pozzolanic strength activity index of the mix based on ASTM C311. After 7 and 28 days of curing, the mortar cubes were then tested for compression strength. Compressive strength of control mixture was compared to the mixture containing pozzolans. The standard states that the compressive strength of blended mortar with pozzolans must be $75 \%$ of the control mortar strength, to be qualified as pozzolanic materials.

\section{Slump test}

Slump test was conducted based on the method specified by ASTM C143 to monitor the consistency of fresh concrete. The test was carried out after the mixing of all materials.

Table 2. Concrete mixture proportions

\begin{tabular}{lccccccc}
\hline \multicolumn{1}{c}{ Mixes } & $\begin{array}{c}\text { Cement } \\
(\mathbf{k g})\end{array}$ & $\begin{array}{c}\text { POFA } \\
(\mathbf{k g})\end{array}$ & $\begin{array}{c}\text { FA } \\
\mathbf{( k g )}\end{array}$ & $\begin{array}{c}\text { Water } \\
(\mathbf{L})\end{array}$ & $\begin{array}{c}\text { Fine } \\
\text { Agg. }(\mathbf{k g})\end{array}$ & $\begin{array}{c}\text { Coarse } \\
\text { Agg. }(\mathbf{k g})\end{array}$ & $\begin{array}{c}\text { SP by weight of } \\
\text { binder }\end{array}$ \\
\hline C100 & 3.15 & - & - & 1.26 & 4.93 & 7.40 & 0.4 \\
C80P20 & 2.52 & 0.63 & - & 1.26 & 4.93 & 7.40 & 0.4 \\
C80P15F5 & 2.52 & 0.47 & 0.16 & 1.26 & 4.93 & 7.40 & 0.4 \\
\hline
\end{tabular}


Table 3. Chemical composition of cement, POFA and FA

\begin{tabular}{|c|c|c|c|c|}
\hline \multirow{2}{*}{\multicolumn{2}{|c|}{ Oxides component }} & \multicolumn{3}{|c|}{$\begin{array}{c}\text { Chemical composition } \\
(\%) \\
\end{array}$} \\
\hline & & Cement & POFA & FA \\
\hline Silicon dioxide & $\mathrm{SiO}_{2}$ & 13.42 & 52.84 & 56.38 \\
\hline Aluminum oxide & $\mathrm{Al}_{2} \mathrm{O}_{3}$ & 2.83 & 9.08 & 17.64 \\
\hline Ferric oxide & $\mathrm{Fe}_{2} \mathrm{O}_{3}$ & 4.35 & 8.67 & 10.97 \\
\hline Calcium oxide & $\mathrm{CaO}$ & 72.86 & 14.01 & 7.77 \\
\hline Magnesium oxide & $\mathrm{MgO}$ & 0.78 & 3.05 & 1.79 \\
\hline \multirow[t]{6}{*}{ Sulfur trioxide } & $\mathrm{SO}_{3}$ & 3.94 & 1.03 & 0.28 \\
\hline & $\mathrm{K}_{2} \mathrm{O}$ & 0.78 & 11.48 & 4.57 \\
\hline & $\mathrm{TiO}_{2}$ & 0.24 & 0.44 & 1.50 \\
\hline & $\mathrm{Na}_{2} \mathrm{O}$ & - & - & 0.88 \\
\hline & $\mathrm{MnO}$ & 0.07 & 0.12 & 0.10 \\
\hline & $\mathrm{P}_{2} \mathrm{O}_{5}$ & 0.36 & 2.50 & 1.55 \\
\hline \multirow[t]{2}{*}{$\mathrm{SiO}_{2}+\mathrm{Al}_{2} \mathrm{O}_{3}+\mathrm{Fe}_{2} \mathrm{O}_{3}$} & & & 70.59 & 84.99 \\
\hline & LOI & 2.50 & 10.01 & 0.38 \\
\hline
\end{tabular}

\section{Compressive strength}

Compressive strength tests of mortar and concrete were conducted to evaluate the mechanical properties of designed concrete. The concrete compressive strength was tested at ages of 7 and 28 days in accordance with ASTM C109. The average will be obtained from the 3 sample cubes per batch at each curing age.

\section{RESULTS AND DISCUSSION}

\section{A. Characterization}

1. X-ray Fluorescence (XRF)

Table 3 shows the chemical composition of cement, raw POFA and FA. These results show that chemical composition of cement is in the standard range. POFA and FA contained very high silica $\left(\mathrm{SiO}_{2}\right)$ content with values $52.84 \%$ and $56.38 \%$ respectively. The total of $\mathrm{SiO}_{2}+\mathrm{Al}_{2} \mathrm{O}_{3}+\mathrm{Fe}_{2} \mathrm{O}_{3}$ for POFA was $70.59 \%$, while FA was $84.99 \%$. XRF results show that both POFA and FA meet one of the requirements of ASTM C618 as pozzolanic materials. The LOI values of POFA and FA are $10 \%$ and $0.32 \%$ respectively. The higher LOI values for POFA indicates that it was not burnt completely at the palm oil mill boiler and still contained some amount of unburned residue. Therefore, heat treatment should be conducted to reduce the LOI value of POFA [15].

\section{Scanning Electron Microscopy (SEM)}

Figure 2 (a), (b) and (c) shows the SEM images of cement, POFA and FA respectively. In general, the results show that POFA is of large and irregular shape with porous structure while FA has small and spherical shape with solid structure. The structure and shape of pozzolans particles play an important role on their physical effect, towards the properties of blended concrete [16].

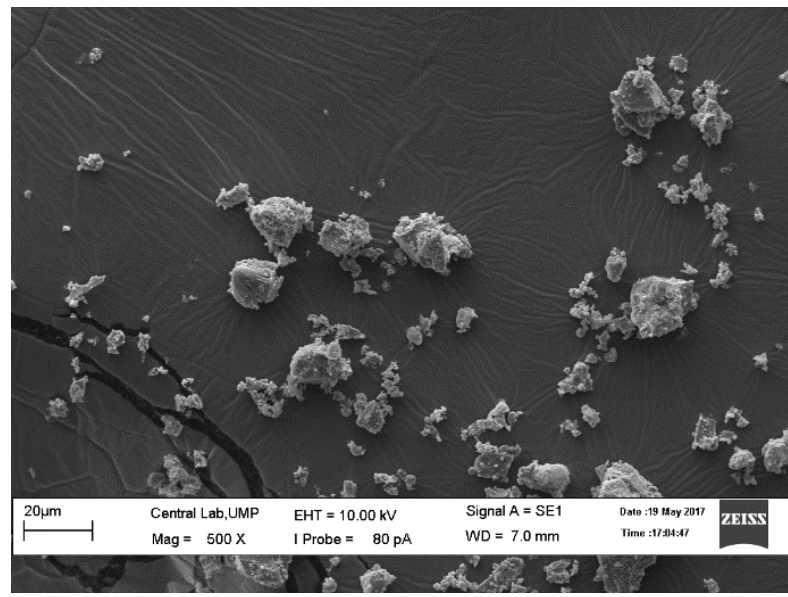

Figure 2 (a). SEM of Cement

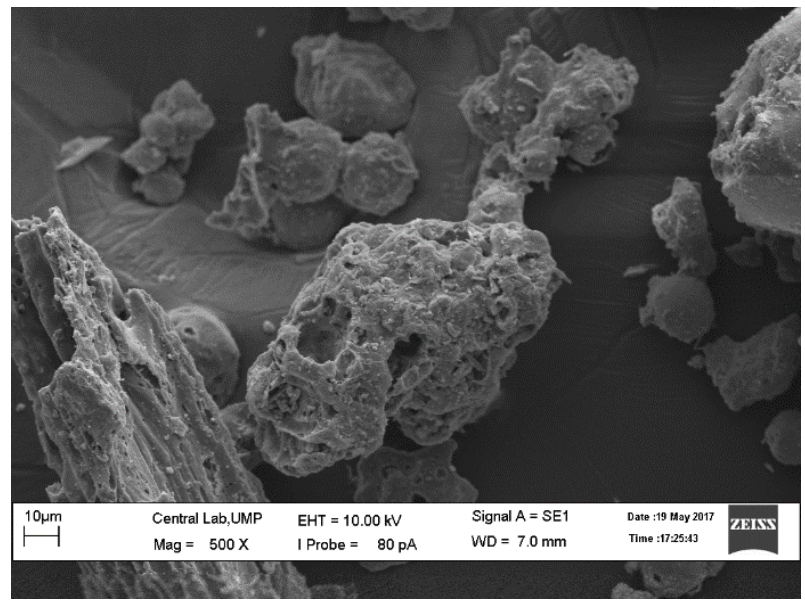

Figure 2 (b). SEM of Palm Oil Fuel Ash

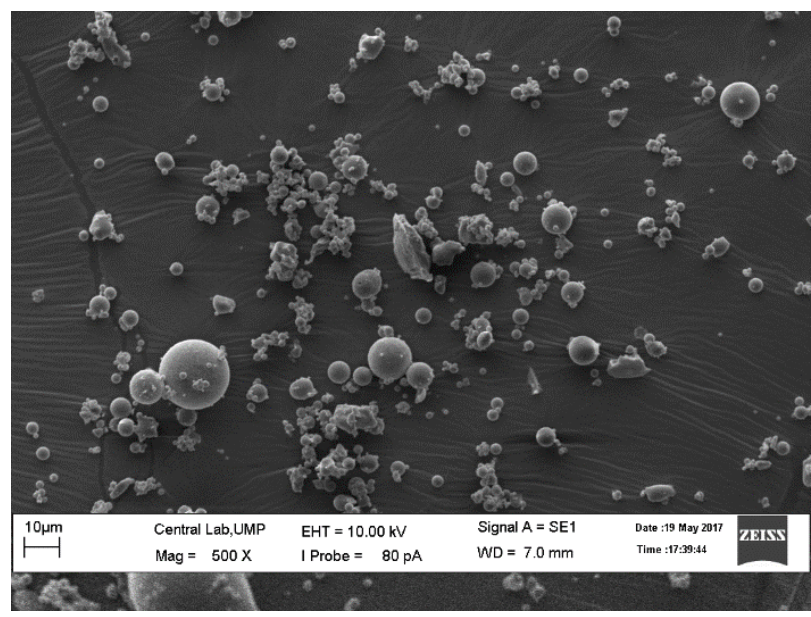

Figure 2 (c). SEM of Fly Ash

\section{B. Pozzolanic Strength Activity Index}

The results of pozzolanic strength activity index are shown in Table 4 and Figure 3. It can be seen that CF obtained the highest strength index with $79.1 \%$ at 7 days and $82.5 \%$ at 28 days. This is due to the higher pozzolanic reactivity of FA. Based on the XRF result, the chemical composition of FA shows that $\mathrm{SiO}_{2}$ and $\mathrm{Al}_{2} \mathrm{O}_{3}$ are higher than the POFA with $56.38 \%$ and 
$17.64 \%$ respectively, which are the main factors affecting their strength index [17]. Pozzolanic reaction occurs due to the reaction of $\mathrm{Ca}(\mathrm{OH})_{2}$ with $\mathrm{SiO}_{2}$ and $\mathrm{Al}_{2} \mathrm{O}_{3}$ from POFA and $\mathrm{FA}$, which produces extra of calcium silicate hydrate, $\mathrm{C}-\mathrm{S}-\mathrm{H}$. Finer size of FA contributes to better pozzolanic activity as well, and increases the surface area of the particles for reactivity.

The lowest strength index was shown by CUP, $60.4 \%$ at 7 days and $70.2 \%$ at 28 days, which did not achieve the required limit of $75 \%$ specified by ASTM C618. CTP shows higher strength index than CUP with $72.2 \%$ at 7 days and $78.3 \%$ at 28 days. CUP and CTP results showed that heat treatment affects the pozzolanic strength activity index of the mortars. Based on Zeyad et al. [18], heat treatment affects the crystallinity of the POFA and increases the $\mathrm{SiO} 2$ content. The particle size of POFA can be one of the reasons as well. Increase in particles size reduced the surface area of particles for pozzolanic reactivity and hence, explained the low early strength of CUP and CTP [19]. At the later age, the strength increased over curing time.

When FA is combined with POFA for mix CUPF and CTPF, it can be seen that the strength index increases. This shows that FA helps the development of strength of CUPF and CTPF mortars. When coarse size particles were mixed with finer size particles, it will create an equilibrium mix as shown in Figure 4. The fineness of FA promotes to higher reactivity of the pozzolans, hence eliminates the poor reactivity of POFA. CTPF showed better result than CUPF because its chemical composition and crystallinity of treated POFA have improved due to the heat treatment process.

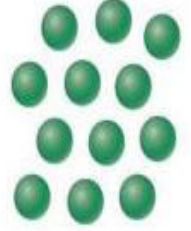

POFA

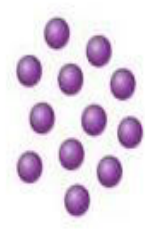

Fine FA Equilibrium mix particles
Figure 4. Equilibrium mixture

Table 4. Pozzolanic strength index

\begin{tabular}{ccc}
\hline Mixes & $\mathbf{7}$ days $(\%)$ & 28 days $(\%)$ \\
\hline CUP & 60.4 & 70.2 \\
CTP & 72.2 & 78.3 \\
CUPF & 70.7 & 76.2 \\
CTPF & 75.9 & 80.0 \\
CF & 79.1 & 82.5 \\
\hline
\end{tabular}

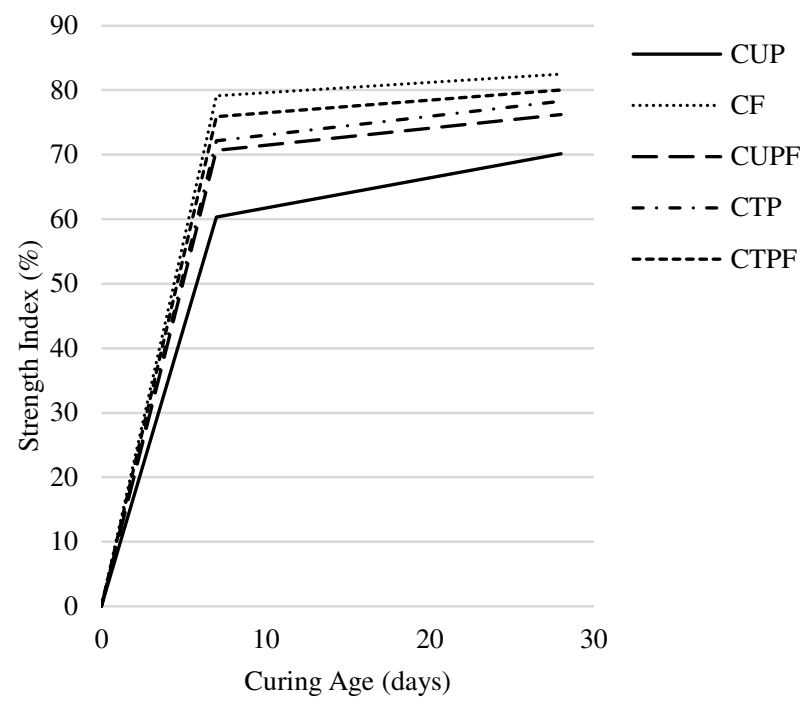

Figure 3. Pozzolanic strength activity indexes of pozzolans

\section{Slump test}

Slump test results are presented in Table 5. The results show that the concrete blended with POFA have lower slump than the control mix. As the SEM results of POFA show that it is in irregular shaped which increases the friction between cement and aggregates. Moreover, the porous structure of POFA increased the water demand of the fresh concrete [20]. Addition of FA improved the workability of fresh concrete. The specimens C80P15F5 showed higher slump than C80P20 because of the spherical shape and solid structure of FA. Bendapudi and Saha [21] found the similar result of workability. C80P15F5 slump was slightly lower than C100 due to higher amount of POFA than FA in the mix.

\section{Compressive Strength}

Table 5 and Figure 4 present the compressive strength development of blended concrete. It can be observed that the strength develops over curing time. The control mix, C100, obtained 28.2 $\mathrm{MPa}$ at 7 days and $31.8 \mathrm{MPa}$ at 28 days. When POFA was replaced with cement for $20 \%$ (C80P20), the compressive strength decreased to $24.2 \%$ for 7 days strength and $26.9 \%$ for 28 days strength. Slower strength development was due to coarse size of POFA. Wunchock et al. [22] investigated on the effect of POFA fineness on the blended cement and stated that "When the POFA was ground to a reasonably high fineness, the rate of compressive strength gain of the blended cement paste was significantly improved due to the hydration reaction, nucleation effect, packing effect and pozzolanic reaction". 
The poor properties of POFA can be improved by adding FA in the blended concrete mix. The results of C80P15F5 showed higher compressive strength compared to C80P20 mix. This is because fine particles size of FA improves the packing effect of coarse POFA hence produced a denser blended concrete. This statement was also supported by Isaia et al., [10] and Rukzon et al., [23]. They stated that incorporation of fine pozzolans in blended concrete improves the strength of concrete due to synergic effects.

Compressive strength of mix C80P15F5 was also compared to mix $\mathrm{C} 100$. At 7 days, the compressive strength of $\mathrm{C} 100(28.2 \mathrm{MPa})$ was higher than the C80P15F5 (27.8 MPa), while at 28 days, C80P15F5 obtained $33.2 \mathrm{MPa}$ compressive strength, which was higher than $\mathrm{C} 100$ which obtained strength of $31.8 \mathrm{MPa}$. The pozzolanic reaction is slow at early age. Pozzolanlime reactions are slow and generally, the reaction will start after one or more weeks. Therefore, C80P15F5 shows higher strength at the later age because of the pozzolanic reaction of pozzolans-lime had occurred. Thus, the mix containing POFA and FA as ternary blend are homogeneous and denser, able to improve the compressive strength of the blended concrete. Chindaprasirt et al. [24] found the similar result of ternary mix POFA and FA showing improved strength. From these results, it can be concluded that POFA can be combined with FA with higher fineness as ternary blend and can be used as a blended pozzolan in blended concrete up to $20 \%$ of cement replacement.

Table 5. Slump and Compressive strength

\begin{tabular}{lccc}
\multirow{2}{*}{ Mix } & Slump $(\mathbf{m m})$ & \multicolumn{2}{c}{ Compressive strength (MPa) } \\
\cline { 3 - 4 } C100 & 80 & $\mathbf{7 ~ d a y s}$ & $\mathbf{2 8}$ days \\
C80P20 & 70 & 28.2 & 31.8 \\
C80P15F5 & 75 & 24.2 & 26.9 \\
\hline
\end{tabular}

\section{CONCLUSIONS}

Based on the results of this study, it can be concluded that:

1. Chemical composition of pozzolans has the significant effect on the pozzolanic strength activity of blended mortar and concrete. Strength properties of concrete blended with combined POFA with FA can be improved because $\mathrm{FA}$ has higher $\mathrm{SiO}_{2}$ and $\mathrm{Al}_{2} \mathrm{O}_{3}$ content.

2. Shape and structure of material particles affect the workability of fresh concrete. Incorporating low amount of FA increased the slump and strength of concrete blended with POFA.

3. Particles size affects the pozzolanic reactivity. Fine particles size of FA helps to improve the packing effect of POFA in blended concrete.

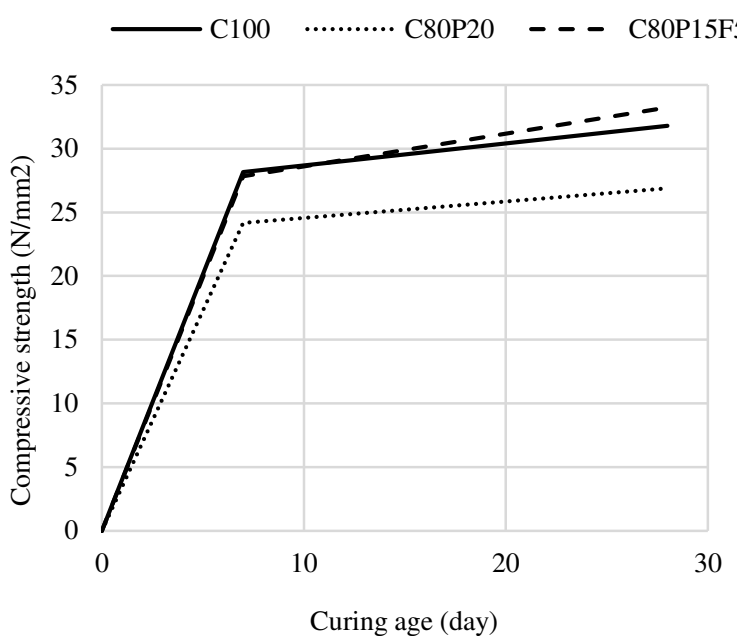

Figure 5. Compressive strength

\section{REFERENCES}

[1] R. Nastaranpoor, "An Investigation for the Effects of Local Natural Pozzolans on Some Mechanical Properties of Concrete," no. August, 2013.

[2] A. Tironi, C. C. Castellano, V. L. Bonavetti, M. A. Trezza, A. N. Scian, and E. F. Irassar, "Kaolinitic calcined clays - Portland cement system: Hydration and properties," Constr. Build. Mater., vol. 64, pp. 215-221, 2014.

[3] B. J. Tay, "A s h from o i 1 - p a $1 \mathrm{~m} \mathrm{w}$ a s t e as concrete m a t e r i a 1," vol. 2, no. 2, pp. 94-105, 1990.

[4] K. Sata, V., Jaturapitakkul, C., \& Kiattikomol, "Utilization of Palm Oil Fuel Ash in High-Strength Concrete," J. Civ. Eng. Manag., vol. 17, no. 2, pp. 234 247, 2004.

[5] M. Ismail, M. a Ismail, S. K. Lau, B. Muhammad, and Z. Majid, "Fabrication of Bricks From Paper Sludge And Palm Oil Fuel Ash," Concrete, vol. 1, no. June, pp. 6066, 2010.

[6] W. Tangchirapat, T. Saeting, C. Jaturapitakkul, K. Kiattikomol, and A. Siripanichgorn, "Use of waste ash from palm oil industry in concrete," Waste Manag., vol. 27, no. 1, pp. 81-88, 2007.

[7] B. H. Nagaratnam, M. E. Rahman, A. K. Mirasa, M. A. Mannan, and S. O. Lame, "Workability and heat of hydration of self-compacting concrete incorporating agro-industrial waste," J. Clean. Prod., vol. 112, pp. 882-894, 2016.

[8] N. Kakhuntodd, P. Chindaprasirt, C. Jaturapitakkul, and S. Homwuttiwong, "The investigation of water permeability of high volume pozzolan concrete," pp. 1-8, 2012.

[9] S. Rukzon and P. Chindaprasirt, "Strength and chloride resistance of blended Portland cement mortar containing palm oil fuel ash and fly ash," Int. J. Miner. Metall. Mater., vol. 16, no. 4, pp. 475-481, 2009.

[10] G. C. Isaia, A. L. G. Gastaldini, and R. Moraes, "Physical and pozzolanic action of mineral additions on the mechanical strength of high-performance concrete," Cem. Concr. Compos., vol. 25, no. 1, pp. 69-76, 2003.

[11] P. Chindaprasirt and S. Rukzon, "Strength, porosity and corrosion resistance of ternary blend Portland cement, rice husk ash and fly ash mortar," Constr. Build. Mater., vol. 22, no. 8, pp. 1601-1606, 2008. 
[12] S. Rukzon and P. Chindaprasirt, "An Experimental Investigation of the Carbonation of Blended Portland Cement Palm Oil Fuel Ash Mortar in an Indoor Environment," Indoor Built Environ., vol. 18, pp. 313318, 2009.

[13] S. M. ahdi Sajjadi, "Binary effect of fly ash and palm oil fuel ash on heat of hydration aerated concrete," ScientificWorldJournal., vol. 2014, p. 461241, 2014.

[14] H. Y. Leong, D. E. L. Ong, J. G. Sanjayan, and A. Nazari, "Suitability of Sarawak and Gladstone fly ash to produce geopolymers: A physical, chemical, mechanical, mineralogical and microstructural analysis," Ceram. Int., vol. 42, no. 8, pp. 9613-9620, 2016.

[15] C. Chandara, K. A. Mohd Azizli, Z. A. Ahmad, S. F. Saiyid Hashim, and E. Sakai, "Heat of hydration of blended cement containing treated ground palm oil fuel ash. Construction and Building Materials," Constr. Build. Mater., vol. 27, no. 1, pp. 78-81, 2012.

[16] M. D. A. Thomas, "Optimizing the Use of Fly Ash in Concrete," Portl. Cem. Assoc., p. 24, 2007.

[17] C. Jaturapitakkul, J. Tangpagasit, S. Songmue, and K. Kiattikomol, "Filler effect and pozzolanic reaction of ground palm oil fuel ash," Constr. Build. Mater., vol. 25, no. 11, pp. 4287-4293, 2011.

[18] A. M. Zeyad, M. A. Megat Johari, B. A. Tayeh, and M. O. Yusuf, "Efficiency of treated and untreated palm oil fuel ash as a supplementary binder on engineering and fluid transport properties of high-strength concrete,"
Constr. Build. Mater., vol. 125, no. March 2017, pp. 1066-1079, 2016

[19] M. Yong, J. Liu, U. J. Alengaram, M. Santhanam, M. Zamin, and K. Hung, "Microstructural investigations of palm oil fuel ash and fly ash based binders in lightweight aggregate foamed geopolymer concrete," Constr. Build. Mater., vol. 120, pp. 112-122, 2016.

[20] N. M. Altwair, S. Kabir, and W. Brameshuber, "Palm Oil Fuel Ash (Pofa): an Environmentally-Friendly Supplemental Cementitious Material for Concrete Production," Int. Rilem Conf. Mater. Sci. (Matsci), Vol Iii, vol. 77, no. March, pp. 113-126, 2010.

[21] S. Bendapudi and P. Saha, "Contribution of fly ash to the properties of mortar and concrete," Int J Earth Sci Eng, vol. 4, no. 6, pp. 1017-1023, 2011.

[22] W. Kroehong, T. Sinsiri, and C. Jaturapitakkul, "Effect of palm oil fuel ash fineness on packing effect and pozzolanic reaction of blended cement paste," Procedia Eng., vol. 14, no. June 2016, pp. 361-369, 2011.

[23] P. Chindaprasirt and S. Rukzon, "Pore Structure Changes of Blended Cement Pastes Containing Fly Ash, Rice Husk Ash, and Palm Oil Fuel Ash Caused by Carbonation," J. Mater. Civ. Eng., vol. Vol. 21; N, no. November, pp. 666-671, 2009.

[24] S. Rukzon and P. Chindaprasirt, "Use of waste ash from various by-product materials in increasing the durability of mortar," Songklanakarin J. Sci. Technol., vol. 30, no. 4, pp. 485-489, 2008. 